\title{
Labor Migration and Gender Empowerment: A Case Study of Housemaids
}

\author{
Farkhanda Shamim ${ }^{1}$, Najeeba Tazeen ${ }^{2} \&$ Naveeda Qaseem ${ }^{3}$ \\ 1 Department of Economics and Finance, University of Bahrain, Bahrain; the Institute of Innovation and \\ Technology Management, Ryerson University, Toronto, Canada \\ ${ }^{2}$ University of Arid Agriculture, Rawalpindi, Pakistan \\ ${ }^{3}$ University of Westminster, London, UK \\ Correspondence: Farkhanda Shamim. Department of Economics and Finance, University of Bahrain, Bahrain; \\ the Institute of Innovation and Technology Management, Ryerson University, Toronto, Canada. E-mail: \\ fshamim@uob.edu.bh
}

Received: November 14, 2013 Accepted: December 1, 2013 Online Published: January 27, 2014

doi:10.5539/ass.v10n3p232 URL: http://dx.doi.org/10.5539/ass.v10n3p232

\begin{abstract}
By applying purposive and convenience sampling techniques the researchers interrogate the reasons of housemaids' migration from their native villages in Northwest Pakistan and their perceived Status within the household. The study finds that due to low wages in their home town, debt bondage, social discrimination based on caste and lack of personal security in the agrarian society, the whole family migrated to cities to improve their living and worked as unskilled labor in urban areas. The study concludes that although women work harder than men once they migrate however, they don't have much control on financial and social decisions and their lives are not any better. Internal migration does help to improve the family's economic and social status but it is not an empowering intervention for the women migrants. Nonetheless, it provides them the possibilities to bring about change in life.
\end{abstract}

Keywords: internal migration decisions, social dynamics, bonded workers, Pakistan, empowerment

\section{Introduction}

The paper has two objectives. First, to investigate and lay out the factors of rural-urban migration. Second, to interrogate the impact of this mobility on the empowerment of low class, unskilled rural workers and its significance for their women.

Empowerment has been defined in many ways, but in general it is considered as a multi-dimensional social process that helps people gain control over their own lives. According to Eyben et al. (2008) empowerment occurs when people "are able to imagine their world differently and to realize that vision by changing the relations of power that have been keeping them in poverty".

The importance of empowerment as a constituent element of human development has been recognized by international organizations such as the United Nations (2001) World Bank (2003) etc and it is one of the Millennium Development Goals to empower socially excluded and disadvantaged members of the society by 2015. In this regard, women empowerment has drawn much attention in recent times and many studies focus on international migration to find its potential to empower women (see Parreñas (2006); Yamanaka (2008) for example). However, such studies are very limited in the context of internal migration and for developing countries. The present study attempts to fill this gap in the literature.

Nonetheless, after having been neglected for a long period in both research and policymaking, it now appears that internal migration itself is receiving growing attention. One such study is done by Selier in 1988 which emphasizes the socio-economic consequences of population mobility in Pakistan context. The paper is structured as follows. First various theories of migration are presented along with important scholarly contributions on empowerment. Then the research methodology and the characteristics of the sample is elaborated followed by the presentation of the research findings on the reasons of migration and its impact on the empowerment of women. Finally, the study is concluded with some policy implications. 


\subsection{Theories of Migration}

Human migration has become a routine in today's world. People leave their hometown for various reasons such as work, study etc. Starting from 1875 till to date there are number of theories which explain how migration processes develop their momentum. However, there is no single migration theory widely accepted by social scientists because migration research is intrinsically interdisciplinary. It involves economics, sociology, political science, law, demography, geography, psychology and cultural studies (Brettel \& Hollified, 2008). Furthermore, There are more migration theories of international significance as compared to the ones for rural-urban migration. Moreover, migration theories hardly address the gender issues in internal migration context partly because in developing countries it is men who migrate first, leaving their families behind who join them later. Apart from this, South Asian societies are different from other parts of the world. Therefore the theoretical predictions about rural-urban migration and its causes developed in the west has little significance in South-Asian context.

Most important theories are listed below.

According to Ravenstein's laws of migration (1875-1889) the primary cause for migration is better external economic opportunities (Daugherty \& Kammeyer, 1995; Bodvarsson Ö,Van den Berg H., 2009). He assumed that "push-pull" factors played important roles in migration. Both push factors such as low wages, high unemployment rates, lack of health care in rural areas and pull factors such as high wages, low unemployment in cities incline people towards leaving their place of residence. Similarly, Harris and Todaro (1970) explain that individuals migrate due to rural and urban wage differentials. Lucas (1997) finds the same outcome for developing countries. While studying rural unskilled workers, KMC. DAM, (1980: 10) points out that the idea of more earning options in the cities stimulate poor people to settle in urban squatter settlements called "katchi Abadis".

On the other hand, Levhari and Stark (1982) and Stark (1991) argue that migration is a collective endeavor to maximize expected income and to minimize risks for the members of the kinship unit. This theory gained much attention, but not many researchers tested it by conducting fieldwork.

Moreover, the importance of social networks is widely recognized among economists (Carrington et al. 1996; Hatton \& Williamson, 1998; Bardhan \& Udry, 1999; Munshi, 2003). Lucas (1997) found that migrants choose destinations where they are well connected. Information about jobs and living standards in the cities are most efficiently transmitted through personal networks such as friends and neighbors who migrated there.

Household strategy theorists contend that migration decisions are not made by individuals but by households. According to the proponents of this approach, people act collectively not only to maximize expected income but also to minimize risks for the members of the kinship unit. Households control risks to their economic well-being by diversifying the allocation of household resources such as family labor (Lauby \& Stark, 1988).

Oishi (2002) discusses the Household Strategy Theory and reports that Rural-urban migration is the migration of people from rural areas into cities. Women follow their fathers or husbands migrate as workers. However, as the number of migrant women increased, the number of abuse and exploitation has also risen. Since most migrant women work at the bottom rung of the occupational hierarchy, they are extremely vulnerable. The vast majority of them work as housemaids, entertainers, nurses, and factory workers. Housemaids are especially vulnerable because they work in private homes where the authority can conduct very little inspection. The problems include sexual harassment, rape, non-payment or underpayment of wages, verbal/ physical abuse, and so on. Discriminatory and cruel, inhuman, and degrading treatment of a vast global population has been justified on the basis of caste.

In this article, we don't adopt one theoretical model. We try to analyze the causes of internal migration taking under consideration all above-mentioned perspectives.

\subsection{Empowerment}

As the story of the human race, from age to age, is full of the struggle to enjoy certain fundamental rights and those rights include freedom from inhuman treatment, freedom from slavery, freedom from discrimination, freedom of thought, assembly and association, and other rights which have always been justified in the name of social norms.

In South Asia, population is divided into layers in an heterogeneous society. This stratification makes for clear distinctions of social class or status. Caste indicates a system of rigid social stratification into groups which are ranked by the society. Social class or caste is descent based and hereditary in nature. Therefore it indicates a system of rigid social discrimination to a group which ranked by the society. One's birth in a particular class determines characteristic of the individual. In this case it is irrespective of faith practiced by an individual 
belonging to a particular class.

As reported by Allport (1979: 321) social class is "a group of people who participate socially with one another on equal terms, or who would be willing to do so. They tend to have similar manners, modes of speech, moral attitudes, educational levels, and comparable amounts of material prosperity"...The classification of different castes is the main cause of discrimination with low cast people of high caste people in Pakistan. This attitude can be defined as prejudice i.e; "an aversive or hostile attitude toward a person who belongs to a group, simply because he belongs to that group, and is therefore presumed to have the objectionable qualities ascribed to the group".

Lewis (1981: 91) describes the allocation of labor on the basis of caste among the Wolof of Senegal. The concept of caste is founded on occupational groups, and accordingly divides Wolof Senegalese into one of four categories, each of which are either hereditary or assumed upon marriage. The "superior" category of the geer is traditionally comprised of farmers, fisherman, warriors and animal breeders. They are still deemed society's noblest. They traditionally can only marry within the group and are not allowed to practice the traditional professions of the lower castes. Although the lower-caste professions are divided among three distinct castes, the jeff-lekk are comprised of artisans while griots and jesters constitute the sab-lekk and noole make up the servants and courtesans.

Human Rights Watch (1995: 12-13) report on Contemporary Form of Slavery in Pakistan interrogates the debt-bondage in Pakistan. It concludes that the debt bondage system is most prevalent in the agricultural provinces of southern Punjab and Sindh. Most laborers in these areas are minority Hindus from lower castes. In a pattern similar to that practiced in India, the charging of exorbitantly high interest rates ensure that loans from landowners never get repaid. While the loan agreement is often made between the landowner and the male head of the peasant household, the work to pay off the loan is performed by the entire family, including women and children. Women have also been held in custody by landowners when bonded male members of the family leave the land or area, and have even been sold into marriage or prostitution should the male family member fail to return. Further reported in Human Rights Watch (1995) that one of the forms of slavery proscribed by the Supplementary Convention on the Abolition of Slavery, the Slave Trade and Institutions and Practices Similar to Slavery of 1956. Pakistani laws, such as the Bonded Labour (Abolition) Act 1992, are consistent with international laws which seek to eliminate the bonded labor system but those laws are not adequately enforced.

Human Rights Watch (1997: 150-52) reports that lower-caste women are singularly positioned at the bottom of caste, class, and gender hierarchies. Largely uneducated and consistently paid less than their male counterparts worldwide they invariably bear the brunt of exploitation, discrimination, and physical attacks. Sexual abuse and other forms of violence against women are often used by landlords and the police to inflict political "lessons" and crush dissent within the community. Lower-caste women also suffer disproportionately in terms of access to health care, education, and subsistence wages as compared to women of higher castes.

According to UNDP (1998) report, the kamaiya bonded labor system is also prevalent in western Nepal. It is stated that kamaiyas are "mostly landless and homeless, and belong to the Tharu ethnic group.... A kamaiya is heavily burdened with debts and often remains as such for a long period. Debts are inter-generationally transferable. Frequently, therefore, a kamaiya household remains in bondage through multiple generations.

Singh (2000: 138) states that scheduled castes are attached to a particular land owning high caste households under "jajmani system" and used to get fixed quantity of cereals at each harvest in lieu of the services rendered to the satisfaction of land owning household through out the year.

Limbu (2001) studied the "low caste (Note 1)" Tarai groups in India and found out that repayment of loans is actively discouraged by the landlords. Because the primary interest of the landlord lies in continued cultivation of his land and in regular assurance of labour supply, his lending is not directed towards earning interest in cash.

GCARCD (2001) notes that women in general and Dalit women of the study in specific represent the most oppressed sections of all societies, and that they face multiple forms of discrimination, including caste-based, religious and patriarchal ideology and practices.

Federal Bureau of Statistics of Pakistan (2002) states that Child labour is common in kilns- nearly half of children (10-14 years) work in kilns, and, surprisingly, so do a significant proportion of smaller children. Arduous work was common at more than 10 hours a day. But two-thirds of labour households had annual incomes smaller than Pakistani Rs (Note 2) 10,000, and only slightly more than $10 \%$ had incomes above Rs 30,000 , equal to current minimum wage of one adult worker. Indebtedness is common, with nearly $90 \%$ taking advances/loans from the kiln-owner because of the absence of alternative credit source. When the employer is 
creditor, the majority have outstanding debt up to Rs 10,000 . However, more than 10 percent have debts above Rs 25,000. Most repay debts through deductions from regular earnings but almost a third also report repayment through additional labour. In reporting the loan repayment period to be indefinite, most workers indicated being tied to kiln labour. Furthermore, the vast majority had inherited their debt. Additional constraints confirmed debt bondage.

Arif, (2004) investigates in his research that bondage in Pakistan is substantive, debt redemption must be excessive in comparison to usual earnings. Lifetime earnings net of even subsistence could never pay back the debt. For smaller debts too, before previous debt can be repaid entirely, additional debt can be required for normal family needs. The exit option can be exercised if the debt is accepted by other family members and they appear capable of redeeming the debt through their own labour. Debts are generally not forgiven upon incapacitation or death. A father or brother must accept the debt of a son or brother; a woman must assume the debt of a husband; and a male child must accept the debt of a father.

Satyani (2005) explains that caste, the scourge of Hinduism, is so deeply entrenched in Indian society that it has not left the adherents of Islam, Sikhism, Christianity and Buddhism-theoretically egalitarian religions-unaffected.

Dike (2005) studies the 'Caste System' in Nigeria and finds that the Africans suffer in the United States are socially similar to those the 'Osu' groups suffer in Nigeria. The only clear difference between "a white person and a black person" is skin pigmentation. But in Nigeria, they are all Negroid but lower caste's sufferings are similar. Any person who has experienced the racial discrimination in the United States will understand the havoc this obnoxious tradition has caused on the so-called 'Osu' groups in Nigeria.

Various theories have been put forward regarding the development of castes among Indian muslims. Some sources state that the castes among Muslims developed as the result of close contact with Hindu culture and Hindu converts to Islam, while others feel that these developed based on the claims of descent from the prophet Mohamed. Ashrafs have a superior status derived from their foreign ancestry, while the Ajlafs are assumed to be converts from Hinduism, and have a lower status. In addition, there is also the Arzal caste among Muslims, who were regarded by anti-caste activists like Babasaheb Ambedkar as the equivalent of untouchables. In the Bengal region of India, some Muslims also stratify their society according to 'Quoms' or castes.

The low caste families migrate from the rural areas to the urban areas. These families are tied in the debt bondage and slavery. To get freedom from slavery they rush to the cities and earn money to repay their debts.

\section{The Universe of the Study}

The purpose of the study is to interrogate the causes of mobility of low class families from their native villages and what impact the mobility has on their lives. We choose Islamabad, the capital city of Islamic Republic of Pakistan to conduct the study because it is one of those big cities of the country where almost every household hires housemaids for their daily chores.

The target population are the women who migrated along with their families from the rural agricultural areas of Punjab and NWFP to Islamabad.

\section{Research Methodology}

By applying purposive and convenience sampling techniques the researchers select 100 respondents of migrated lowest income group from rural area to Islamabad. To collect data, following procedure is adopted.

First the researchers select two key informants through personal contacts. One is a 30 years old woman who has been working in the area for last five years and lives in the tent. She was a useful informant about the tent living. Another woman of 51 years old is the second key informant. She has been in Islamabad for 9 years, living in Katchi Abadi (houses made of clay), and her husband works in the form house nearby. She gave information about those maids who live in clay houses. Key informants facilitated the entry of the researcher into the locale. Being housemaids both were up to date and had handsome knowledge of the locale and were such persons who had good rapport with people from whom data related to the topic could be obtained.

Second, the researchers tried to establish good rapport in their community with the help of the key informants and by taking certain confidence building measures like wearing very simple cloths, talking in their dialect and by sitting in their tents after their work hours. In order to create a climate of trust and confidence the researchers bring sweets and toys for their kids. By spending time in the respondent's houses they slowly but gradually started discussion about their migration related issues and problems of their lives. The researchers believe that this personal approach provided more accurate and reliable data. 
Third, after establishing a good rapport in the community, the researchers started conducting in-depth interviews from 20 respondents to get the full information and narrate in detail about the topic. Half of them live in the tents and others live in the clay house. The researchers conducted in-depth interviews in order to verify and to cross-check the data gathered by survey. Through this technique the researchers got extensive descriptive information in the form of narratives, actions and events that helped to analyze all aspects of the problem under investigation.

Forth, semi-structured interviews are conducted of 80 housemaids to fill up the questionnaire. The questions are open ended according to the situation and the response of the participants.

The study therefore uses both qualitative and quantitative data. The questionnaire is used to explain the factors behind migration in a broader perspective. These quantitative data is augmented by a smaller set of qualitative data obtained through the in depth interviews. The interviews were taken in a due physical and socio-cultural environment with few distractions to achieve the research objectives.

\subsection{Characteristics of the Sample}

- The respondents are the women who migrated from the rural agricultural areas of Punjab and NWFP to Islamabad.

- The living conditions are very poor with almost no sanitation system.

- The respondents can't read or write.

- Most of the respondents belong to the 15-34 years of age group.

- Almost all with very few exemptions respondents are married and have 4-7 children on average.

- 50 percent of the respondents have 5 to 9 members in the family and 22 percent having family size 10-14. Only 28 percent of respondents have their family size less than 5 .

- 48 percent respondents earn $\$ 18$ per month on average. Only 10 percent respondents earn $\$ 40$ per month. The income figures overall show low wages for those who were ill, pregnant or elderly.

- However, the monthly income of families from all resources was about up to Rs. 2000 of 20 percent families. 32 percent families monthly income was ranged between Rs. 2100-4000. it also showed Rs.4100-6000 earned by 38 percent families. And only 4 percent of families showed the income ranged between Rs. 6100-8000. Monthly income was only 6 percent of families. During in-depth and structured interviews, it was noticed that majority of the respondent's children were also work as maids in different houses. The husbands of those respondents earned approximately Rs.2000 per month.

- While comparing the family size and the family income it is observed that 9 out of 10 respondents with family income up to Rs. 2000 per month had family size less than ten. 16 respondents with family income more than Rs. 2000. it also indicates that 20 families were those whose income was Rs. 2100-4000 and Rs. 4100-6000 with less than 10 family members. As the number of members increased monthly income also increased. 5 families were those who's monthly income was more than Rs. 6000 and their family members were more than 5-14. Not a single respondent with family income more than Rs. 6000 per month had family size less than 5 .

- 72 percent of the main breadwinner of the family are women and in only 28 percent families the chief earners is a man. Since women work as housemaids and men as construction agent or laborer and housemaid jobs are somewhat permanent jobs as compared to construction job, therefore females turn into main breadwinner of the family.

- 16 percents of women were earning alone without the help of any one. Only 8 percent of respondents helped by 3 other members of the family. The respondents were mostly helped by their children. The cause of 1 earner of the family was the drug addiction of male family member and had small kids so in that case only housemaid was the chief earner of the family.

- $\quad 46$ percent respondents migrated to the city in last 5 years. 28 percent were migrated 6-10 years before. 12 percent of the respondents migrated 11-15 years ago and also 14 percent of respondents were migrated there from more than 15 years.

\section{Analysis and Discussion}

In this paper, the questionnaire and the interview findings are presented together. We discuss the reasons of migration followed by their level of empowerment. 


\subsection{Reasons of Migration}

The people who belong to the low caste move to cities with their entire families to earn money and better their lives. It is noticed that these families have social and economic problems in their native village. Originally, they are homeless people and if their landlord gives them a room to live they have to be there for generations. To better their lives both female and male members of the families migrate and work as unskilled labor in urban areas. The study confirms household strategy theories. It is also confirmed by the study findings of Lauby and Stark (1988) that migration decisions are made by households not by individuals.

The reasons of migration, highlighted by the respondents are as follows.

\subsubsection{Low Wages}

The term low labor cost was used by many of the respondents that at the place of origin the daily labor was Rs. 120 and in some of the cases that was about Rs. 20 or Rs. 50 per day. Many times it was happened that there was no labor for them by the landlord at that time they were job less. By working on brick kiln they gave Rs. 100 upon 1000 bricks. It was very hard for them to survive with small mount of money. In some cases the land owner gave no cost for there labor but only at the end of the season one canvas bag of wheat was given to them.

As one of the respondents told the researcher that "The land owner gave only Rs.20 per day to my husband for his whole day work. It was very hard for us to survive with a small amount of money. Me, my husband and my children had to survive for many days without eating any thing."

Another respondent informed: " my husband is paralyzed by one leg, we were not having enough money to checked up my husband from Doctor".

During in-depth interviews many women discussed the problem that the landlord give them a room to live. So he could ask for the work any time without paying in the form of money to them. The reason was, in this case they were permanent Kammi (employee) of their zameendar (landlord).

This was also justified in the finding of Singh (2000), Lewis (1981) and Selier (1988).

\subsubsection{Debt Bondage}

Debt bondage was another reason of migration of low castes. They took it because there is no other option for the survival of these families. The landlord gave them no money so that they must not be independent. The landlord wanted his kami bonded in debt. They were bonded by kiln owner or the land owner but in both the cases lifetime earnings net of even subsistence could never pay back the debt. Another reason of debt bondage was to get money for their daily activities because owner gave them money only to eat bread. But other necessities of life were also importance. During the in-depth interviews with maids they told researcher that to arrange the marriage of their children they were bound to take the debt from landlord. Bondage applied on families. After the death of husband the wife or his son had to pay that there was no relaxation in any situation.

As one of the respondents told about her debt bondage that "my husband was addicted of drugs and to fulfill his requirements he took debt from the Zameendar. And day by day the amount of debt increased as Rs. 20,000 and I was the only one who had to pay all the debt. Now I came here and want to earn money as much as I can so that I could return all the debt to the Zameendar".

The finding of the study led to the general statement that freedom from slavery was one of the reason of migration. In the agricultural sector, where credit is critical for survival until the harvests, peasants depend on non-institutional sources of credit. Peasants must purchase agricultural inputs, equipment, and basic necessities before the harvests. For example, sharecroppers, who have no direct access to institutional credit, are forced to rely on their landlord for seasonal loans. Dependence on landlords for credit leaves peasants vulnerable to debt-bondage. Failed harvests, common occurrences in Pakistan, often result in such limited options for economic survival that peasants must literally mortgage themselves to a landlord. If poor economic conditions continue and workers cannot repay their loans, they become permanently bonded to their landlord.

During the research it was also found that if the debt was not paid until the particular time given by the landlord then he could take Rs.4000 interest per month. One researcher told about her bondage that she had taken Rs. 25,000 debt from the landlord and contract for 1 year to repay the debt. She told that if she would not be able to return back then after one year landlord will add Rs. 4000 per month (16\% interest rate per year). This was the reason of her migration to earn money by doing job as housemaid and return the debt of landlord.

The findings are in line with Human Rights Watch (1995), UNDP (1998) and Arif (2004). 


\subsubsection{Dependency}

During the in-depth interviews every respondent told that "we feel independent here". It was found that the reason of their satisfaction was economic and social independency. They were restricted, socially bound and economically dependent upon landlord. By earning money for the betterment of their children and well being of their family it could also possible to repay their debt and build houses in their origin. Building a house was the dream of majority of the respondents. In their native village the male members had some labor but females had no labor. In many cases only one person was the bread earner and many were to eat. But after their migration both husband and wife earn which helped the betterment of their family.

They could have better medical facilities for the family although they had to pay for it.

If any of them want their children to go to school they could independently do that because there was no restriction of education.

The findings are in line with Human Rights Watch (1997).

\subsubsection{Social Discrimination}

Another reason of the majority of the respondents to migrate was the social discrimination faced by many of the respondents at their origin. Although these low castes were habitually of being victim of verbal abuses but as the modern age came so every one is aware of their social rights.

As a respondent mentioned that "here the educated people call us with respectable names such as baji, maasi, khala, ama jee. (Note 3) These names gave us self respect. But in our origin every one call us in a very insulting way".

The caste system is an ascribed or imposed status. It is also appropriate to touch on the issue of culture, because culture, in one way or another, influences the propagation of the caste system. As the definitions show, the culture of a community influences the behavior of the people, and the pace of its socioeconomic development.

As another respondent of 45 years old told that "my husband is a kidney patient. I was not able to get his treatment because of the social discrimination and economic dependency on others. "

\subsubsection{Personal Security}

The majority of loans that are extended to bonded laborers are given to men. As a consequence, female bonded laborers are faced with double exploitation as dependents of male bonded laborers. Such women rarely receive financial compensation; they are expected to work full-time, over and above maintaining their households. Some of the women claim that they had personal insecurity. As they were bonded by the landlord so he could sell their children or any of the family members because he had the full right to do so. Children either work alongside their bonded families or sold individually into bondage.

A respondent mentions that my sister with her husband and children were sold by landlord to his friend. And they could not come to the village or go any where. I had never seen my sister from 7 years. We all fell threatened. But here we feel relax regarding our security.

The findings are in line with Arif (2004) study.

\subsection{Migrant Women's Perceived Status within the Household}

Given the complex nature of the issue, a concise definition of women empowerment in a household is not possible. Therefore, the definition (Note 4) of the United Nations Population Information Network is adopted for this study which considers following points while measuring women's empowerment; women's relative monetary contribution to the household and ownership over their earnings, improved role in household decision-making, and their perceived status within the household (Handapangoda, 2012). Since the study is about migrant unskilled workers, we ignored many factors of women empowerment which other researchers ( Malik \& Courtney, 2011; Pitt, Khandker and Cartwright, 2003) studied such as controlling savings and loans, political awareness, etc.

The survey findings are presented as follows:

\subsubsection{Control over Income and Savings}

The migrant women are the sole bread winners of the households. In $80 \%$ of the households, drug addicted men work as unskilled workers and spend their earnings on buying drugs.

"My husband earns for his drugs not for his children", told one respondent.

However, they have no right on their salaries. They have to give the whole salary to their husbands. 


\subsubsection{Decision Making}

The women were asked how their households arrived at decisions such as kids education, buying household utensils etc. $58 \%$ of women questions responded that their husbands make all important decisions at home. However, roughly $19 \%$ of the respondents answered that they and their husbands jointly decided about household affairs. The rest of the respondents said that the woman makes most of the decisions at home.

\subsubsection{Family Planning}

In the sample, majority of the families (73\%) were not planning their family. Among couples who were using family planning methods, $96 \%$ reported that it was the woman who was using birth control methods. As one of the respondents said, "she had never been able to make her husband use a male birth control method".

\subsubsection{Spousal Abuse}

It was found during the survey that the women who work hard for their families are also frequently abused by their partners. Since the woman is tired of working whole day in various houses, man is drunk, so an argument on minor issues will lead to verbal abuse in $70 \%$ cases and physical abuse in $40 \%$ cases.

One of the respondents told her painful story, "I got married when I was 10 years. My husband was about 15-20 years old than me. He beats me every day and some days even I could not go to my work because of the pains which I still have."

\section{Concluding Remarks}

The main purpose of the study was to investigate the reasons of low caste migration from rural areas to the urban areas of Pakistan and what impact the mobility has on their lives. Although the caste system was the Indian system but as the other traditions of Indian culture are deep rooted in Pakistani society social stratification were also privileges. This makes the clear distinction of low class and high class. The exploitation of low-caste laborers and the rigid assignment of demeaning occupations on the basis of caste keep lower-caste populations in a position of economic and physical vulnerability. The triple burden of caste, class, and gender effectively ensures that lower-caste women are the farthest removed from legal protections.

By applying purposive and convenience sampling techniques the researchers select 100 respondents of migrated housemaids from rural area to Islamabad.

The findings confirm household strategy theory that the whole family migrate to cities to better their lives and work as unskilled labor in urban areas. Due to low wages in their home town, debt bondage, dependency on landlords for their social, economic and financial needs, social discrimination based on caste, absence of social rights, and lack of personal security in the agrarian society, the low caste workers migrate to cities to improve their living. Although women work harder than men once they migrate to city, but they don't have much control on financial and social decisions and their social lives are not any better. Spousal abuse persists, family planning does not exist and are made by men. In short, internal migration does help to improve the family's financial status but it was not an empowerment for the women migrants. Nonetheless, it provided them the possibilities to bring about change in life.

\section{Acknowledgements}

The authors gratefully acknowledge the professional guidance and moral support of Dr. Abdul Saboor and Dr. Farooq Tanwir in the earlier draft of this paper.

\section{References}

Allport, G. W. (1979). The Nature of Prejudice. Addison-Wesley Publication Company, 25th anniversary edition.

Arif, G. M. (2004). Bonded labour in agriculture: A rapid assessment in Punjab and North West Frontier Province, Pakistan. Working paper No. 25, International Labour Office, Geneva.

Bardhan, P., \& Udry, C. (1999). Development Microeconomics. Oxford Scholarship Online. http://dx.doi.org/10.1093/0198773714.001.0001

Bodvarsson Ö., V. B. H. (2009). The Economics of Immigration: Theory and Policy. Heidelberg, Germany: Springer-Verlag.

Brettell, C. B., \& Hollifield, J. F. (2008). Migration Theory. Talking across Disciplines (2nd ed.). Routledge, New York and London.

Carrington William, J., Detragiache, E., \& Tara, V. (1996). Migration with endogenous moving costs. American Economic Review, 86(4), 909-930. 
Daugherty, H. G., \& Kammeyer, K. C. W. (1995). An Introduction to Population. Guilford Press, NY.

Dike, V. (2005). The 'Caste System' in Nigeria, Democratization and Culture: Socio-political and Civil Rights implications. Africa Economic Analysis. Retrieved July, for $\mathrm{http} / / / \mathrm{www}$. africaeconomicanalysis.org/articles/gen/castehtm.html

Eyben, R., Kabeer, N., \& Cornwall, A. (2008). Conceptualising Empowerment and the Implications for Pro Poor Growth. Paper prepared for the DAC Poverty Network. The Institute of Development Studies, Brighton.

Federal Bureau of Statistics. (2002). Social Finance Programme. International Labour Organization, Geneva.

GCARCD. (2001). Final Declaration Of the Global Conference Against Racism and Caste-based Discrimination: Occupation and Descent-based Discrimination Against Dalits.

Handapangoda, W. A. (2012). Can Money Buy Them Power? A Re-Evaluation of Women's Transnational Labor Migration and their Household Employment in Sri Lanka. Women Studies, 41, 558-582. http://dx.doi.org/10.1080/00497878.2012.683707

Harris J. R., \& Todaro, M. P. (1970). Migration, Unemployment and Development: A two-sector analysis. Retrieved July, 2013, from http://www.aeaweb.org/aer/top20/60.1.126-142.pdf

Hatton, T. J., \& Williamson, J. G. (1998). The Age of Mass Migration. Oxford University Press, New York.

Human Rights Watch. (1995). Contemporary Forms of Slavery in Pakistan. Human Rights Watch, New York.

Human Rights Watch. (1997). Broken People. In reviewing India's third periodic report to the U.N. Human Rights Committee. Consideration of Report by India to the Human Rights Committee. CCPR/C/79/Add.81.

KMC. DAM. (1980). A place to live. A report on Katchi Abadi Improvement in Karachi. Metropolitan Co-operation Dutch Advisory Mission. Karachi. Pakistan.

Lauby, J., \& Stark, O, (1988). Individual Migration as a Family Strategy: Young Women in the Philippines. Population Studies, 42(3), 473-486. http://dx.doi.org/10.1080/0032472031000143596

Levhari, D., \& Stark, O. (1982). On Migration and Risk in LDCs. Economic Development and Cultural Change, 31.

Lewis. (1981). "The First Senegal". Abdoulaye-Bara Diop, La Société Wolof: Tradition et Changement. Les Systèmes D'Inégalité et de Domination. Paris. Karthala.

Limbu, R. (2001). Lacking homes, freed peasants squat on government land. Inter Press Service.

Lucas, R. E. (1997). Internal Migration in Developing Countries. In M. Rosenzweig, \& O. Stark (Eds.), Handbook of Population and Family Economics (Vol. 1B.). Amsterdam: Elsevier Science Publishing. http://dx.doi.org/10.1016/S1574-003X(97)80005-0

Malik, S., \& Courtney, K. (2011). Higher Education and Women's Empowerment in Pakistan. Gender and Education, 23(1), 29-45. http://dx.doi.org/10.1080/09540251003674071

Mark, M. P., Khandker, S. R., \& Cartwright, J. (2003). Does Micro-Credit Empower Women? Evidence from Bangladesh. Working Paper 2998. World Bank Policy Research.

Marten, L. K. (1988). Squatter settlement in Pakistan. Vanguard book (Pvt) Islamabad.

Munshi, K. (2003). Networks in the Modern Economy: Mexican Migrants in the US Labor Market. Quarterly Journal of Economics, 549-599. http://dx.doi.org/10.1162/003355303321675455

Oishi, N. (2002). Gender and Migration: An Integrative Approach. The Center for Comparative Immigration Studies. University of California, San Diego. 79-80.

Pakistan Institute of Labour, Education \& Research. (2004). Unfree labour in Pakistan: Work, debt and bondage in brick kilns.

Parreñas, R. S. (2006). Caring for the Filipino Family: How Gender Differentiates the Economic Causes of Labor Migration. In A. Agarwa (Ed.), Exploring Migrant Women and Work (pp. 95-115). London. Sage Publications.

Satyani, P. (2005). The Situation of the Untouchables in Pakistan. ASR Resource Center.

Selier, F. J. (1988). Migration in Pakistan (Theories \& Facts). Vanguard Books Ltd. Lahore Pakistan.

Shaheed, F., \& Mumtaz, K. (1987). Women in Pakistan. Two steps forward, one step back? Zeb Books Ltd. London/ New Jersey. 
Singh, S. K. (2000). Dalit Women, Socio Economic Status and Issues. New Royal Book Co. Lucknow.

Stark, O. (1991). The migration of labor. B. Blackwell (Cambridge, Mass., USA and Oxford, UK).

Stark, O. (2006). Inequality and migration: A behavioral link. Economics Letters, 91(1) 146-152. http://dx.doi.org/10.1016/j.econlet.2005.09.015

UNDP. (1998). Nepal Human Development Report. United Nations Development Program. Oxford University Press, New York.

United Nations. (2001). Road map towards the implementation of the United Nations millennium declaration. Report of the Secretary-General, United Nations. New York. Retrieved from http://unpan1.un.org/intradoc/groups/public/documents/UN/UNPAN004152.pdf

UNPOPIN. (2009). United Nations Population Information Network. Guidelines on Women's Empowerment. POPIN, Department of Economic and Social Affairs, with support from the UN Population Fund (UNFPA).

World Bank. (2003). Gender equality and the Millennium Development Goals. Washington. Gender and Development Group. Retrieved from http://siteresources.worldbank.org/INTGENDER/Publications/20706126/gendermdg.pdf

Yamanaka, K., \& Piper, N. (2005). Feminized Migration in East and Southeast Asia: Policies, Actions and Empowerment. United Nations Research Institute for Social Development.

\section{Notes}

Note 1. low caste include professions like Musahar, Dusadh, Dom, Chamar, Musalli.

Note 2. Exchange rate for the Pakistan Rupee (Rs) against US dollar is 0.00965 approximately.

Note 3. baji, maasi, khala, ama jee means sister, auntie etc.

Note 4. For the full definition UNPOPIN n.d. (2009)

\section{Copyrights}

Copyright for this article is retained by the author(s), with first publication rights granted to the journal.

This is an open-access article distributed under the terms and conditions of the Creative Commons Attribution license (http://creativecommons.org/licenses/by/3.0/). 